\title{
SARANA KETERAMPILAN SENI DIGITAL
}

\author{
Giovani Onawa ${ }^{1)}$, Stephanus Huwae ${ }^{2)}$ \\ 1)Program Studi S1 Arsitektur, Fakultas Teknik, Universitas Tarumanagara, giovani_onawa@yahoo.com \\ 2) Program Studi S1 Arsitektur, Fakultas Teknik, Universitas Tarumanagara, ituuuuut@yahoo.com
}

\begin{abstract}
Abstrak
Tingginya urbanisasi juga persaingan lapangan kerja yang ketat oleh generasi milenial membuat mereka sangat sulit kerja. Keterbatasan softskill sebagai kunci utama yang membuat mereka harus terpaku dengan menjadi seorang pegawai. Keterampilan merupakan kunci penting untuk bisa dimiliki oleh milenial sebagai altenatif permasalahan tersebut. Keterampjlan juga merupakan aspek yang mampu menciptakan kontribusi positif berupa pembangunan dan perekonomian kreatif yang berkembang pesat. Karena dengan karakteristik milenial yang kreatif, saling terhubung dan percaya diri mengarahkan perkembangan jaman menjadi industri kreatif. Oleh karena itu bagaimana arsitektur dapat mewadahi aktivitas -aktivitas keterampilan mereka itu dengan memberikan sebuah fasilitas atau sarana yg bertujuan tidak hanya sebagai wadah kerativitas tetapi sebagai wadah untuk memberikan interaksi kepada orang lain.
\end{abstract}

Kata kunci: ekonomi; industri; interaksi; sarana kreatif

\begin{abstract}
The high level of urbanization is also dominated by the millennial generation which enables the creation of positive contributions in the form of development and a rapidly developing creative economy. Because with creative millennial characteristics, interconnection and confidence, they lead to the development of the era into a creative industry. Therefore, architecture can accommodate their skill and its activities by providing a facility that aims not only as a place of creativity but as a place to provide interactions for one another.
\end{abstract}

Keywords : economy; industry; creative; means; interaction

\section{PENDAHULUAN}

Provinsi DKI Jakarta memiliki jumlah penduduk milenial yang cukup besar dan heterogen. Hal ini dikarenakan Jakarta memiliki daya tarik dalam aspek ekonomi, politik, pendidikan, dan lainlain, sehingga tingkat urbanisasi di Provinsi DKI Jakarta menjadi sangat tinggi. Tingginya urbanisasi juga membawa berbagai masalah kesenjangan sosial seperti kemiskinan yang disebabkan oleh persaingan yang ketat dan terbatasnya lahan pekerjaan.

Berdasarkan Badan Pusat Statistik 2017 jumlah pengangguran di Jakarta meningkat dari tahun sebelumnya mencapai 346.940 ribu jiwa dengan Tingkat Pengangguran Terbuka (TPT) sebesar 7,14 persen dari total angkatan kerja. Angka ini meningkat dibandingkan dengan posisi Februari 2017 hanya 5,36 persen maupun dari posisi Agustus 2016 sebesar 6,12 persen. Tingkat pengangguran di lbu Kota tersebut juga jauh di atas TPT nasional, yakni 5,5 persen. Berdasarkan artikel kreditgogo tahun 2014 penyebab dari sulit kerja bagi para milenial adalah kurang linkage dan kurang terampil. Penyebab kurang terampil itu sendiri bisa berasal dari sekolah atau universitas sebagai tempat belajar mereka, yang membuat output pelajar sebagai pegawai bukan sebagai problem solving, hal ini diperkuat oleh data dari world economic forum indonesia berada di peringkat 3 terbawah se-ASEAN. namun timbul sebuah pertanyaan bagaimana solusi untuk mengisi daya terampil pada milenial; pertama, bisa melalui pendekatan keterampilan melalui sebuah hobi, sebagai aktivitas yang sering dilakukan, namun media apa yang bisa menunjang hobi untuk para milenial.

Seni merupakan salah satu media yang tepat yang tidak hanya menunjang aktivitas hobi bagi milenial namun dapat menghasilkan sebuah karya serta bisa diperjual belikan. Seni juga sejalan dengan program industri kreatif karena menekan individu untuk menghasilkan sesuatu yang 
kreatif serta memiliki nilai jual itu sendiri. Menurut Menteri Keuangan Sri Mulyani Indrawati, dari permasalahan ekonomi yang terjadi dapat diselesaikan melalui industri kreatif yang juga merupakan pilihan utama para generasi milenial dalam mengejar karir di lapangan pekerjaan yang baru, pada tren sektor jasa sangat berkembang dan maju. Karena dengan karakteristik yang kreatif dan inovatif adalah strategi dalam meningkatkan pertumbuhan ekonomi. Industri kreatif adalah "Industri yang berasal dari pemanfaatan kreatifitas, keterampilan serta bakat individu untuk menciptakan kesejahteraan serta lapangan pekerjaan melalui penciptaan dan pemanfaatan daya kreasi dan daya cipta individu tersebut" (Pengembangan Ekonomi Kreatif Indonesia 2025, 2008). Subsektor dalam industri kreatif meliputi beberapa bidang, antara lain: periklanan, arsitektur, pasar barang seni, kerajinan, desain, fesyen, video film, dan fotografi, permainan interaktif, musik, seni pertunjukan, penerbitan dan percetakan, layanan computer dan piranti lunak, televisi dan radio, serta riset dan pengembangan. Industri kreatif memiliki kontrubusi yang tinggi dalam pertumbuhan ekonomi Negara karena menjadi sumber pendapatan dari pemasaran baik local maupun internasional. Industri kerajinan tangan (kriya) merupakan subsektor industri kreatif yang punya kontribusi paling besar untuk nilai ekspor, serta kedua terbesar untuk nilai konsumsi rumah tangga. Kontribusi tersebut merupakan yang terbesar ketiga dari industri kreatif Indonesia secara keseluruhan, menurut data dari BEKRAF tentang kontribusi PDB Ekonomi kreatif.

Tingginya urbanisasi juga didominasi oleh generasi milenial yang mampu menciptakan kontribusi positif berupa pembangunan dan perekonomian kreatif yang berkembang pesat. Karena dengan karakteristik milenial yang kreatif, saling terhubung dan percaya diri mengarahkan perkembangan jaman menjadi industri kreatif. Oleh karena itu bagaimana arsitektur dapat mewadahi aktivitas -aktivitas keterampilan mereka itu dengan memberikan sebuah fasilitas atau sarana yg bertujuan tidak hanya sebagai wadah kerativitas tetapi sebagai wadah untuk memberikan interaksi kepada orang lain.

\section{KAJIAN LITERATUR}

\section{Keterampilan}

Menurut Gordon (1994), Keterampilan adalah kemampuan seseorang dalam mengoperasikan pekerjaan secara lebih mudah dan tepat. Pendapat tentang keterampilan ini lebih mengarah pada aktivitas yang bersifat psikomotorik. Sedangkan menurut Dunette (1976) Keterampilan merupakan pengetahuan yang didapatkan dan dikembangkan melalui latihan atau training dan pengalaman dengan melakukan berbagai tugas.

Keterampilan di bagi menjadi 4 kategori sebagai berikut:

- Basic Literacy Skill: adalah suatu keahlian dasar yang dimiliki oleh setiap orang seperti menulis, membaca, mendengarkan, maupun kemampuan dalam berhitung.

- Technical Skill: adalah suatu keahlian yang didapat melalui pembelajaran dalam bidang teknik seperti menggunakan komputer, memperbaiki handphone, dan lain sebagainya.

- Interpersonal Skill: yaitu keahlian setiap orang dalam melakukan komunikasi antar sesame, seperti mengemukakan pendapat dan bekerja secara dalam tim.

- Problem Solving: yaitu keahlian seseorang dalam memecahkan masalahnya dengan menggunakan logikanya.

\section{Penyebab kurangnya keterampilan}

Menurut Seth Godin, satu-satunya tujuan sistem pendidikan adalah untuk melatih orang agar mau bekerja di pabrik. Permasalahan yang terjadi pada sistem sekolah saat ini :

- Industrial age values, selalu terpaku pada instruksi yang diberikan, tidak berinisiatif.

- Lack of autonomy, diatur sesuai sistem yang ada.

- Inauthentic learning, sistem pembelajaran yang verbal bukan untuk pemecahan masalah.

- No room for passion, tidak ada nya ruang untuk kegiatan hobi, sistem pembelajaran lecturing, terpaku dengan lisan, tidak interaktif. 


\section{Potensi generasi milenial terhadap kerajinan tangan}

Dari observasi penelitian yang dilakukan oleh Peneliti Pasar Pamela N. Danziger, hal yang penting adalah outlet kreatif untuk ekspresi diri. Diketahui berdasarkan data Badan Pusat Statistik (BPS) tahun 2015 yang diolah Ditjen IKM Kemperin menunjukkan ada 695.000 jumlah industri kayu, barang dari kayu dan gabus (tidak termasuk furnitur), barang anyaman dari rotan, bambu dan sejenisnya. Setiap tahunnya nilai tambah IKM ini terus melonjak naik, diketahui pada tahun 2014 nilai tambah sekitar Rp 25,356 triliun, dan pada tahun 2015 naik menjadi Rp 26,743 triliun.

\section{METODE}

Metode dalam penelitian ini terdiri dari dua metode kualitatif. Untuk jenis kualitatif terdiri dari:

\section{- Studi observasi}

Studi observasi merupakan studi yang menggunakan 5 indra untuk mengamati langsung di lapangan. Metode ini dipakai oleh penulis dalam mengamati kawasan Gambir, Jakarta Pusat.

- Fenomenologi

Fenomenologi merupakan metode yang digunakan penulis untuk menyelidiki sebuah fenomena dari perspektif individu atau beberapa individu yang mengalaminya. Metode ini dipakai oleh penulis untuk melihat bagaimana karakter generasi milenial dan aktivitas penduduk di sekitar kawasan Gambir, Jakarta Pusat.

- Wawancara

Wawancara merupakan, proses memperoleh keterangan untuk tujuan penelitian dengan bertanya jawab serta berinteraksi antara peneliti dengan objek penelitian. Metode ini dipakai oleh peneliti dengan mewawancarai penduduk - penduduk sekitar kawasan Gambir, Jakarta Pusat terutama anak - anak muda.

Dalam penyelesaian masalah menggunakan metode tipologi ruang kegiatan menurut Gunarwan Tjahjono, kegiatan manusia bersifat mendasar yang berkonsekuensi terhadap pemakaian ruang dan syarat yang dihasilkannya. Tipe ruang kegiatan tersebut dapat menampilkan suatu penyelesaian. Dalam menganalisis batas ruang gerak kita sering mengaitkan nama ruangan dengan kegiatannya. Namun nama tidak menggambarkan tipe, melainkan model, yang tipe nya perlu ditelusuri lagi.

Bangunan ini di desain dengan pendekatan metode Kontekstual Regionalism dimana bangunan di desain berdasarkan konteks lingkungan dan bersifat mikro. Pada metode ini bangunan harus peka terhadap bahasa local arsitektur. Bahasa local bisa meliputi iklim sekitar, aktivitas sekitar, orientasi dan pola bangunan sekitar maupun tipikal bangunan sekitarnya. Dikarenakan bersifat mikro, Hasil akhir dari produk arsitektural ini bersifat arsitektur modern, kemudian program bangunan juga bisa dijadikan hasil akhir dari metode tersebut.

Dari metode ini diimplementasikan kedalam bangunan melalui sebagai berikut:

- Daerah sekitar memiliki ketinggian bangunan yang cenderung beragam dari 2-4 lantai (Iow rise) hingga 8-12 lantai (high rise) sehingga diimplementasikan ke dalam bangunan ini sebagai transisi diantara ketinggian bangunan - bangunan lain nya. Massa bangunan ini memiliki ketinggian yang berbeda - beda sehingga terjadi pola yang berundak - undak.

- Orientasi bangunan dilihat dari 2 hal yaitu; arah matahari dan orientasi bangunan terhadap jalan. Posisi matahari mempengaruhi zonasi pada bangunan, terutama ruang - ruang yang tidak terpapar langsung oleh cahaya matahari, respon kedua untuk mengatasi sisi yang terkena matahari langsung dengan menggunakan secondary skin sehingga menciptakan bayangan, mengurangin panas sinar matahari yang masuk, juga untuk menyaring pembuangan udara keluar bangunan.

- Aktivitas pada lingkungan terdiri dari pekerja kantor dan pelajar yang diadaptasikan kedalam bangunan berupa ruang - ruang publik seperti coworking space, café dan exhibition yang diletakkan pada bagian depan bangunan. 


\section{DISKUSI DAN HASIL}

\section{Program}

Pengertian dari fungsi kegiatan bangunan menurut teknik pengaturan zonasi, yaitu :

- Studio Keterampilan : Tempat yang digunakan untuk kegiatan mengasah kecakapan, dan berlatih seperti membuat studi foto, studio film, studio TV, kartun, atau musik.

- Tempat Kursus dan Pelatihan : Tempat jalur pendidikan di luar pendidikan formal yang dapat dilaksanakan secara terstruktur dan berjenjang. yang dihargai setara dengan hasil program pendidikan formal setelah melalui proses penilaian penyetaraan oleh lembaga yang ditunjuk oleh Pemerintah atau Pemerintah Daerah dengan mengacu pada standar nasional pendidikan. Tema utama dari program ini, kerajinan tangan (kriya) dipilih berdasarkan:

a. Potensi industri kreatif yang berkembang dan tinggi peminatnya khususnya dikalangan generasi milenial. Dari industri kreatif seni kriya merupakan salah satu subsector unggulan karena meningkatkan perekonomian Negara dan permintaan ekspor yang tinggi dari luar Negara.

b. Menjawab permasalahan Generasi Millennial yang kurang memiliki keterampilan dalam pekerjaan mandiri

c. Berdasarkan karakteristik milenial yang kreatif dan inovatif, sehingga dapat menciptakan produk yang unik dan bernilai daya saing

d. Tujuan dari program sarana keterampilan seni kriya adalah mengedukasi dan meningkatkan produktivitas untuk mengurangi masalah pengangguran, melalui industri kreatif dapat membuka lapangan pekerjaan yang menciptakan hasil produk kreatif dan inovatif.

e. Karena bangunan ini mengangkat aspek sosial, target pengguna untuk program ini adalah generasi milenial pada daerah sekitar, di kecamatan Pulo Gadung dan sekelilingnya, baik bagi penghuni, pelajar terutama tingkat pendidikan SMK, universitas dan setaranya, serta masyarakat pengangguran di Jakarta. Karena pada titik tersebut sudah berpikir kritis, kreatif dan inovatif sehingga ada peluang untuk mengembangkan potensi keterampilan mahasiswa. Kemudian komunitas juga berperan untuk mendukung aktivitas ini dengan proses pembelajaran, pelatihan dan bertukar pikiran.

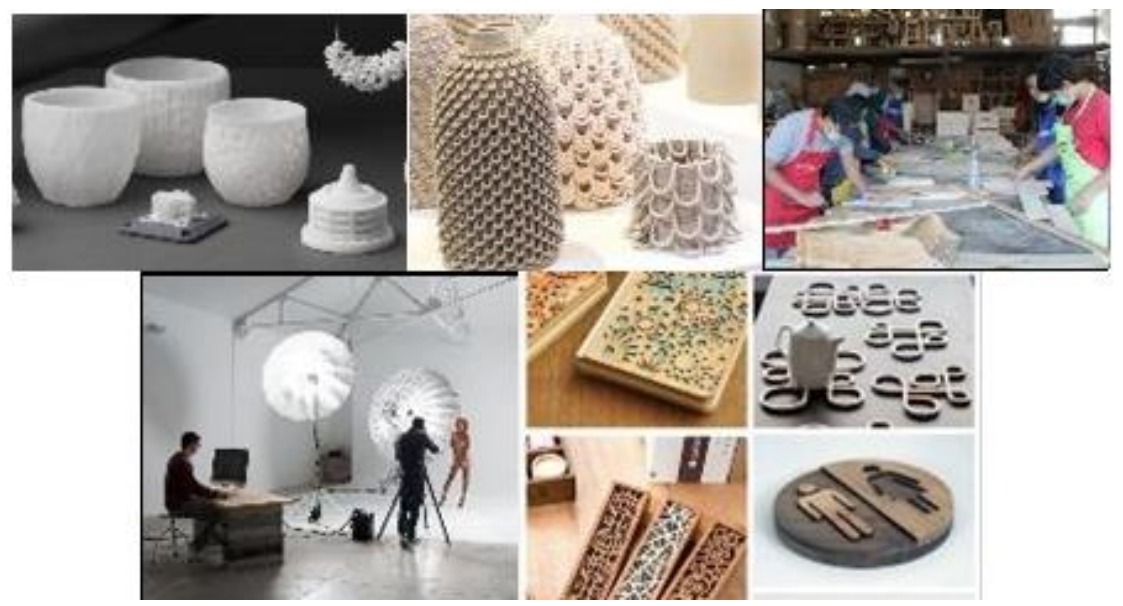

Gambar 1. Produk Kerajinan

Sumber: Penulis, 2019

Terdapat 5 jenis program utama workshop dalam bangunan ini yaitu: Laser Cutting, 3D Printing, Virtual Pottery, Fashion dan Woodworking. Program ini didapat dari program organisasi kerajinan tangan provinsi DKI Jakarta (DEKRANASDA) yang memiliki produk unggulan Pottery, kayu dan fashion. Dari perkembangan jaman dan tren milenial dalam keterampilan menggunakan teknologi mesin untuk 3D Printing dan Laser Cutting dalam menciptakan karya - karya seni yang presisi, rapih dan effisien. 


\section{Lokasi}
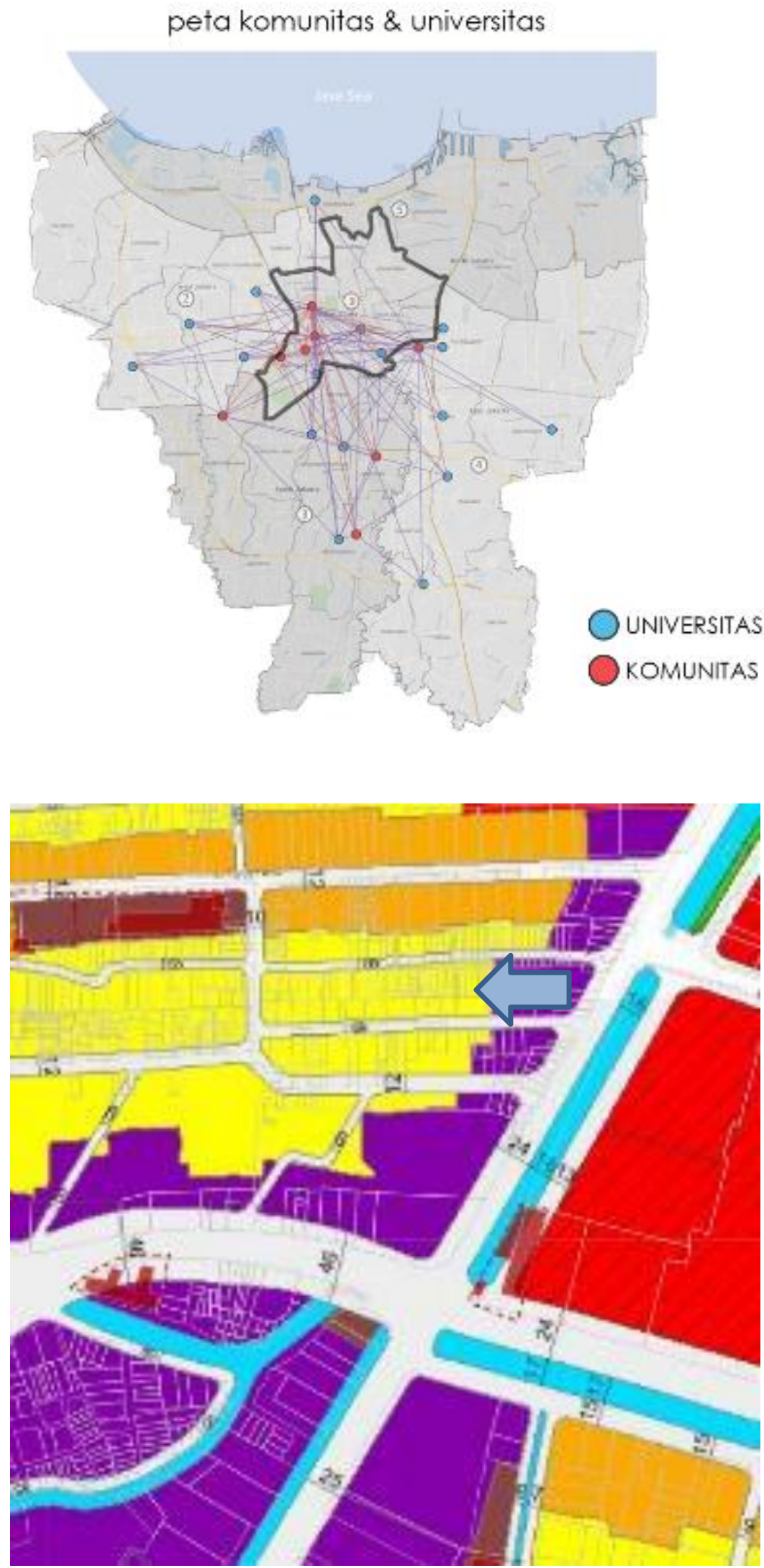

Gambar 2. Pemilihan Tapak

Sumber: Penulis, 2019 
Dengan peruntukan lahan sebagai berikut :

Tabel 1 : Detail Zonasi

\begin{tabular}{llll}
\hline \multicolumn{4}{l}{ Zona K.1 : Zona Perkantoran, Perdagangan dan Jasa } \\
\hline KDB & 60 & KTB & 55 \\
\hline KLB & 2.4 & Tipe & D \\
\hline KB & 4 & PSL & P \\
\hline KDH & 30 & &
\end{tabular}

Sumber : Jakarta Satu

Tapak dipilih berdasarkan mapping titik - titik komunitas dan universitas kesenian di Jakarta, dari titik - titik tersebut ditarik simpul yang saling berhubungan dari komunitas ke universitas juga dari antar komunitas dan universitas, simpul ini menandakan bahwa terdapat konektivitas seperti event, workshop dan studio yang menggabungkan beberapa komunitas tersebut. Kawasan yang paling dominan titik nya terletak di Gambir, Jakarta Pusat. Tapak ini juga berdekatan dengan lembaga pusat kesenian seperti Jakarta Creative Hub (JCH), Jakarta Design Center (JDC), DEKRANASDA dan Komunitas kecil lainnya.

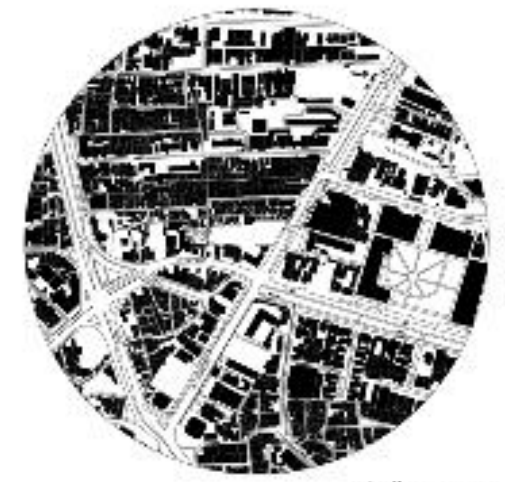

Noll; nec

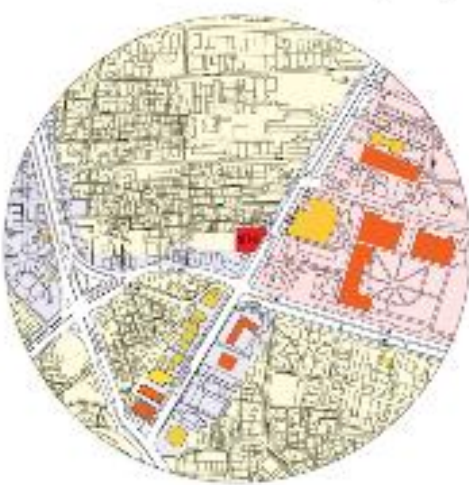

Ketingegian tonguner

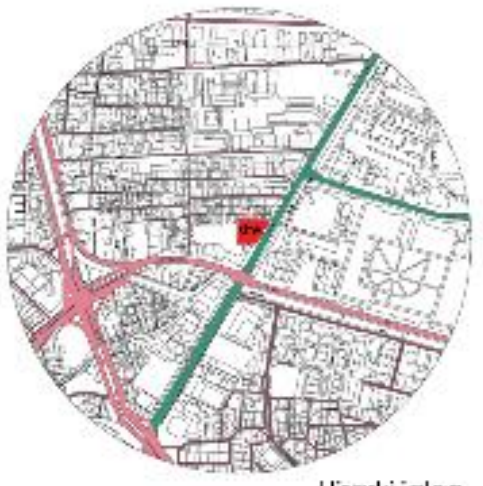

Hirarki alor

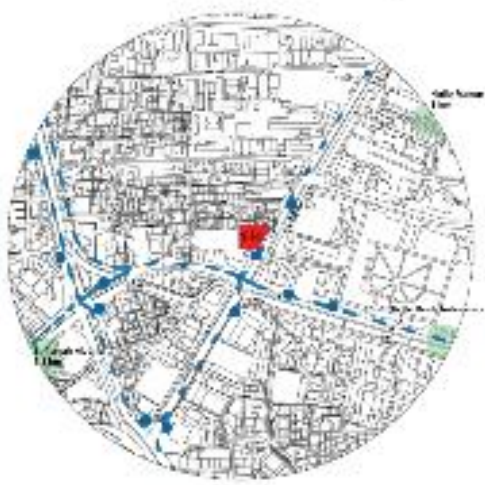

tronsocitosi

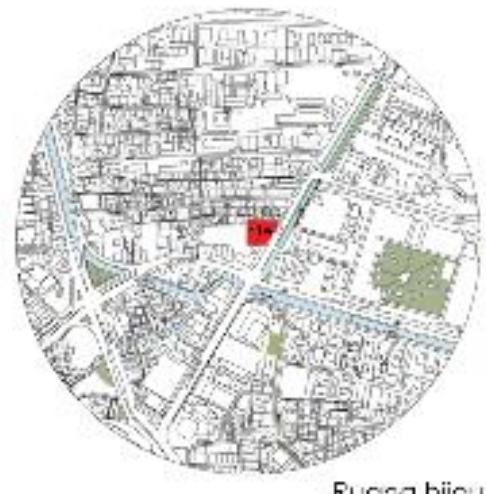

Ruong hijou

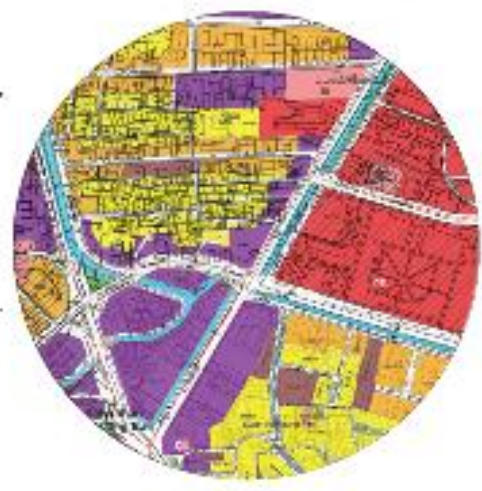

zonosi

Gambar 3. Analisa Tapak Makro

Sumber: Penulis, 2019

Kawasan Gambir, Jakarta Pusat merupakan kawasan yang cukup padat dan memiliki pola bangunan yang organik dan teratur, untuk yang organik berada di jalan - jalan lokal sedangkan untuk bangunan teratur berada pada sisi jalan arteri dan kolektor. Ketinggian bangunan juga beragam dari low rise hingga high rise yang tersebar secara acak, untuk bangunan low rise berada pada sisi dalam dari jalan, sedangkan high rise berada di sisi jalan yang menuju kearah Thamrin. 


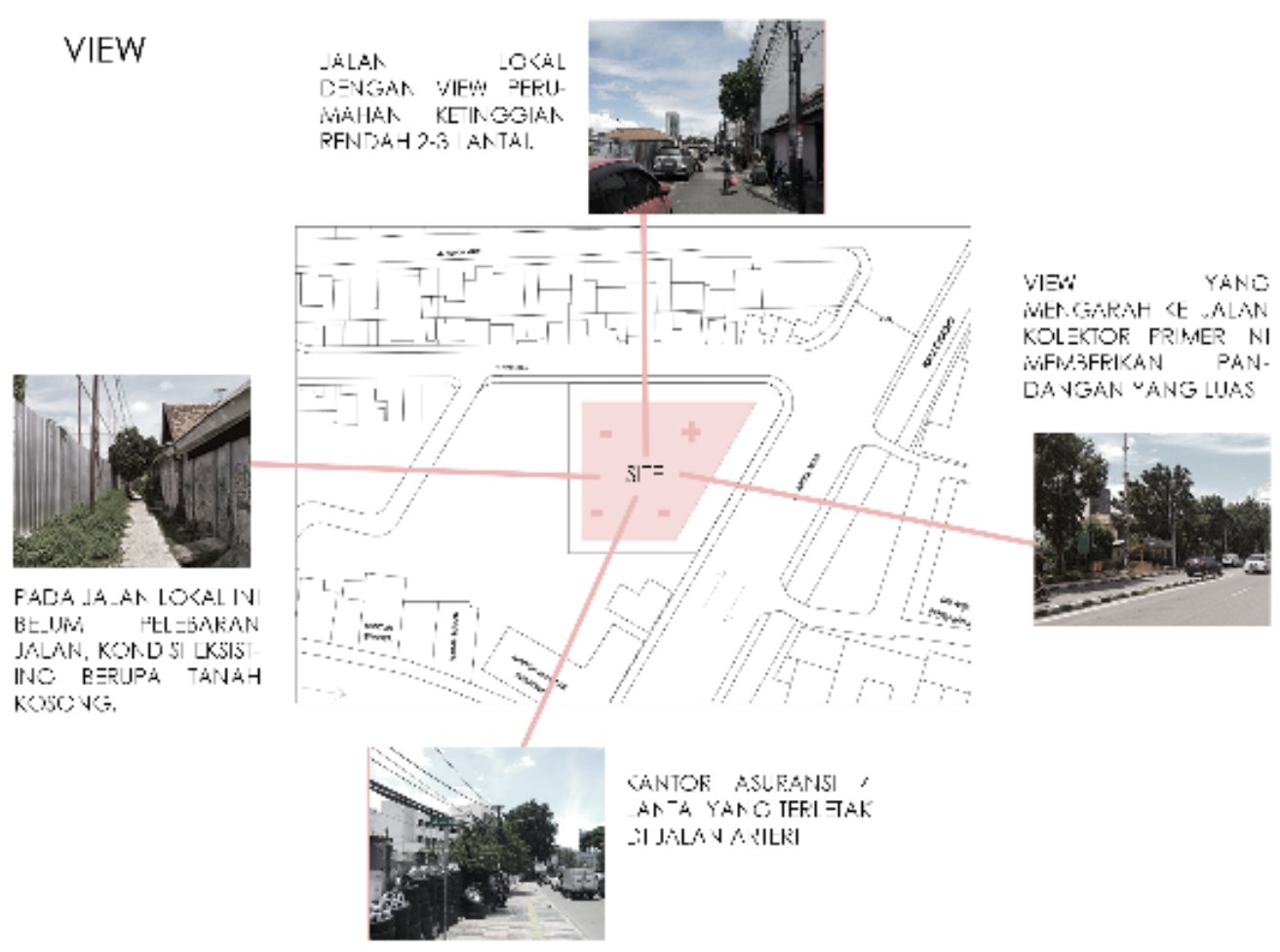

Gambar 4. Analisa Tapak Mikro

Sumber: Penulis, 2019

Site yang dipilih berada pada Jalan Abdul Muis yaitu jalan kolektor. Tapak yang berbentuk trapesium dengan sudut yang cukup tajam. Bangunan disekeliling tapak sebelah Barat merupakan tanah kosong, sebelah Utara merupakan perumahan 1-3 lantai, sebelah Timur merupakan bangunan 2-8 lantai, dan sebelah Selatan merupakan bangunan kantor 4 lantai. View di sekitar tapak ini tidak memiliki pemandangan ataupun penghijauan maka dari itu untuk view bangunan berada di dalam berupa innercourt yang berguna sebagai penghijauan pada bangunan.
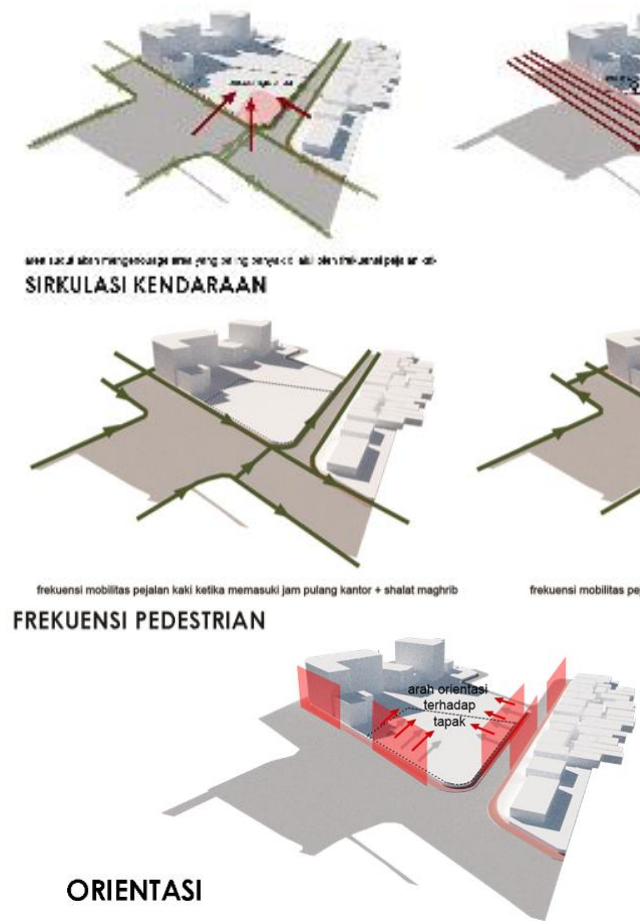

Gambar 5. Analisa Tapak Mikro

Sumber: Penulis, 2019
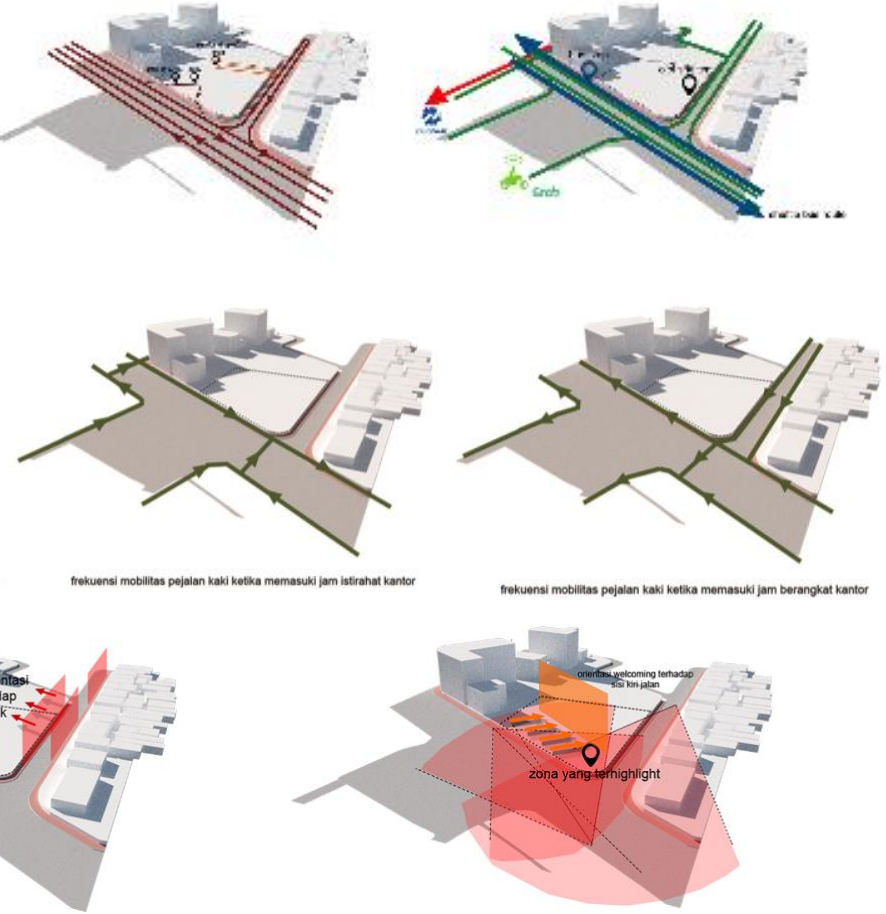
Sirkulasi kendaraan yang masuk kedalam tapak dilewati oleh 2 lajur dan 4 jalur pada Jalan Abdul Muis dan 2 lajur 2 jalur pada Jalan Kebon Jahe 3. Frekuensi yang paling padat dilalui di jalan Abdul Muis, maka dari itu enterance mobil ke dalam bangunan dialihkan ke jalan lokal untuk mengurangi terjadinya kemacetan. Pada depan tapak terdapat halte bus Jatibaru, ini digunakan sebagai shelter ojek online pada bagian depan bangunan.

Dengan adanya halte bus maka frekuensi pedestrian yang berlalu lalang melewati sepanjang tapak, dari kost pekerja ke kantor, dan dari kantor ke tempat makan di sekitar Abdul Muis. Maka sudut pada tapak digunakan sebagai enterance pedestrian dari jalan dan shelter. Sedangkan untuk loading dock mobil barang memiliki sirkulasi enterance dari Jalan Kebon Jahe 3 dan keluar di Jalan Abdul Muis. Jalur servis ini berada di pinggir batas tapak dengan lebar 4 meter.

Orientasi pada bangunan dilihat dari 2 tipe; yaitu orientasi bangunan sekitar pada sisi jalan dan orientasi oleh iklim bangunan. Bangunan disekitar sisi jalan mencondong kearah timur laut sedangkan bangunan lainnya yang berada di jalan lokal mengarah kea rah utara selatan dengan tipe deret. Bentuk bangunan juga perlu menarik pengunjung yang lewat menggunakan kendaraan, dari zona yang ter highlight sudut pada tapak perlu mencondong kedepan agar tidak tertutup oleh bangunan 4 lantai yang ada di sebelahnya.

\section{Hasil}

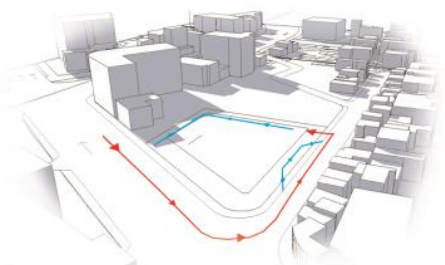

SIRKULASI PENCAPAIAN
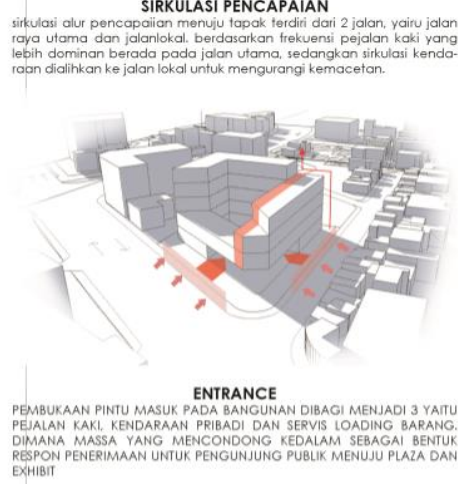

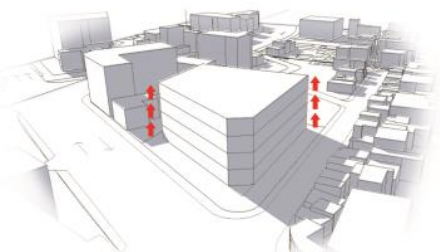

PENEKANAN MASSA
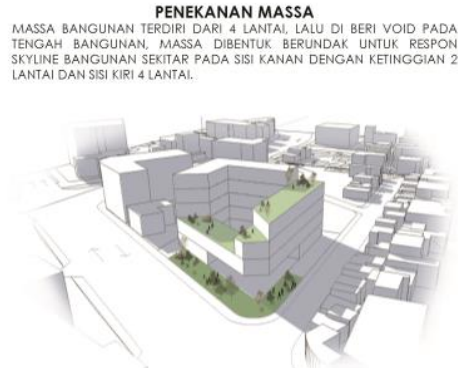

LANDSCAPE

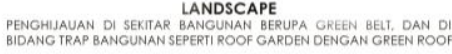

Gambar 6. Proses Gubahan Massa

Sumber: Penulis, 2019
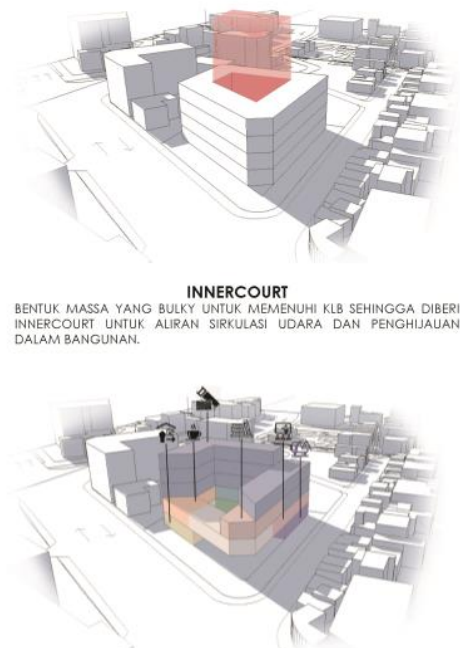

ZONING

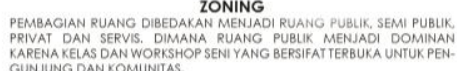

Hasil dari analisa tapak pada sirkulasi pencapaian datang dari arah Tanah Abang menuju Menteng merupakan jalur utama, masuk dan keluar kendaraan pada bangunan berada di sisi samping tapak. Lalu massa dibentuk sesuai maksimal ketentuan KLB 2.4 dari luas tapak 2910 m $^{2}$ yaitu $7003 \mathrm{~m}^{2}$ sebanyak 4 lantai. Lalu penempatan innercourt di dalam bangunan untuk penghijauan dan penipisan massa agar tidak terlalu tebal, juga untuk sirkulasi udara dan view kedalam bangunan. Massa pada bagian depan di sisi jalan dibuat berundak - undak untuk peralihan ketinggian bangunan disekitarnya yang memiliki perbedaan dari 4 lantai ke 2 lantai. Untuk bagian yang berundak digunakan sebagai aktivitas outdoor dan penghijauan seperti roof garden.

Zonasi pada bangunan di bagi dari publik, semi publik, private dan servis. Lantai 1 terdiri dari publik seperti lobby, plaza, exhibition dan art shop dan sebagian servis seperti loading dock dan gudang. Untuk lantai 2 terdiri dari zona publik seperti café dan coworking space, zona semi publik seperti function room dan zona semi private seperti kantor pengelola. Untuk lantai 3 terdiri dari zona publik untuk perpustakaan dan communal space dan zona semi publik untuk workshop laser 
cut dan fashion. Untuk lantai 4 untuk workshop woodworking, 3D printing dan virtual pottery. Lantai 5 untuk studio basic modeling dalam penggunaan aplikasi program untuk laser cut dan 3D print. Setiap ruang - ruang workshop memiliki karakter ruang yang berbeda dalam satu konsep yaitu terbuka, untuk memperlihatkan aktivitas workshop sehingga pengunjung dapat melihat proses nya dan tertarik untuk mengikuti proses pembelajaran nya, hasil karya nya juga akan dipamerkan dan di perjual belikan sehingga dapat membuka peluang usaha / entrepreneur.

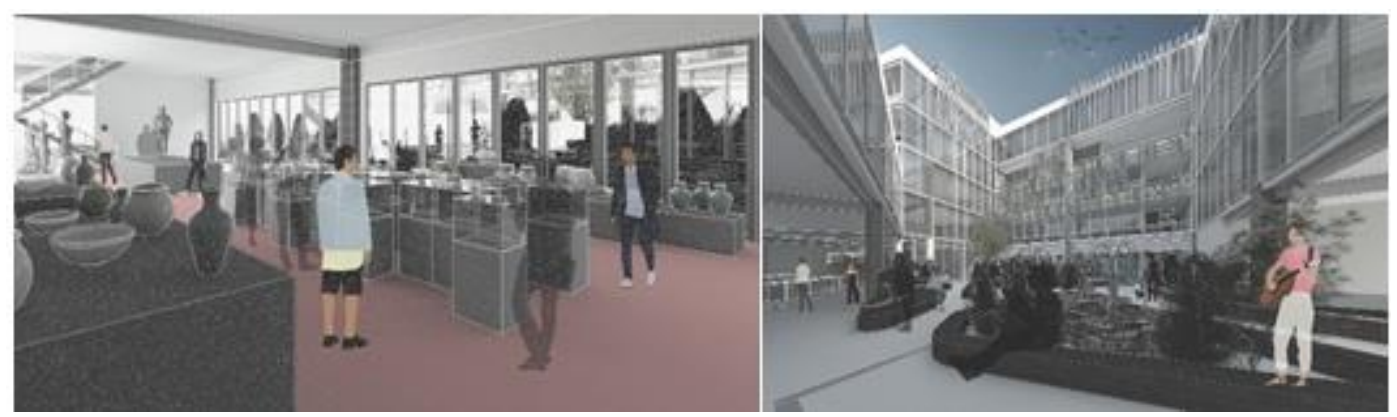

Gambar 7. Interior exhibition dan innercourt Sumber: Penulis, 2019
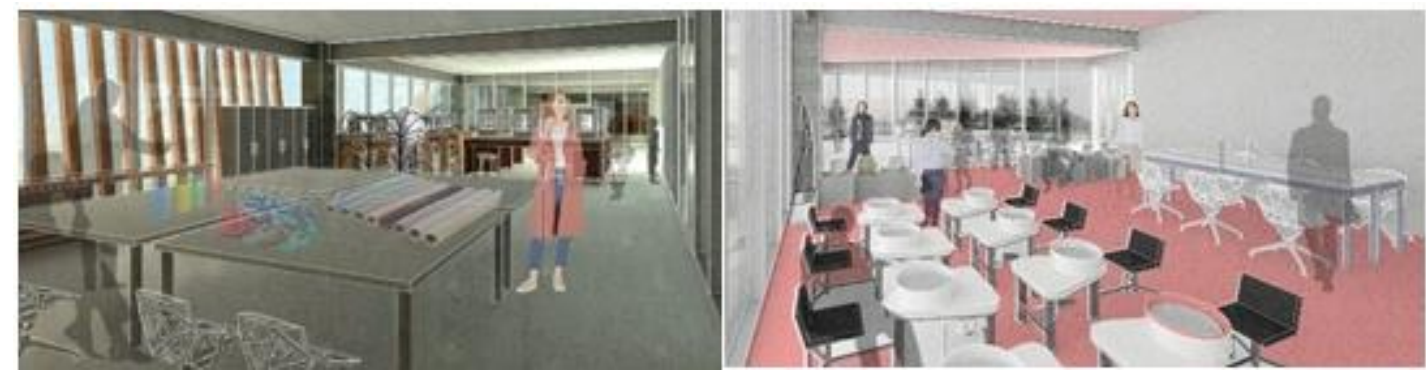

Gambar 8. Interior workshop fashion dan pottery Sumber: Penulis, 2019

\section{KESIMPULAN DAN SARAN}

Dari masalah generasi milenial yang susah mencari kerja diberikan solusi usaha mandiri atau wirausaha melalui industri kreatif karena mereka mempunyai potensi dari pendidikan yang sudah diajarkan untuk berpikir kritis, inovatif, dan kreatif. Walau demikian sistem pendidikan tersebut mengarah ke tenaga kerja karyawan yang tidak memiliki kemampuan teampil, sehingga sarana keterampilan ini sebagai modal secara dini sebelum memasuki dunia kerja.

\section{REFERENSI}

Anggraeni, R. (2018). Sri Mulyani: Industri Kreatif Bisa Menjadi Solusi Pertumbuhan Ekonomi. Diakses pada 23/07/ 2019, dari https://ekbis.sindonews.com/read/1352739/33/srimulyani-industri-kreatif-bisa-menjadi-solusi-pertumbuhan-ekonomi-1541597725

Afiff, F. (2012). Kewirausahaan Dan Ekonomi Kreatif. Jakarta: Binus University

BPS. (2017). Angka Pengangguran Jakarta di Atas TPT Nasional. Jakarta: BPS

BPS. (2018). Kepulauan Seribu, Kabupaten/Kota Termiskin di Jabodetabek. Jakarta: BPS

Kota Administrasi Jakarta Timur. (2019). Potensi Wilayah. Diakses 23 / 07/ 2019, dari https://timur.jakarta.go.id/v11/?p=potensi.wilayah

Ihsanuddin. (2018). Sandiaga: Pengangguran Anak Muda Indonesia Tertinggi di ASEAN. Diakses pada 23/07/ 2019, dari https://nasional.kompas.com/read/2018/08/29/13051731/sandiaga-pengangguran-anakmuda-indonesia-tertinggi-di-asean

Kurniawan, F. (2018). Situasi Genting Angkatan Kerja Indonesia. Diakses 23/ 07/ 2019, dari https://tirto.id/situasi-genting-angkatan-kerja-indonesia-cFal 
Sukmana, Y. (2018). Lulusan SMK Penyumbang Penggangguran Tertinggi, Ini Kata Menaker. Diakses pada 23/07/ 2019, dari https://ekonomi.kompas.com/read/2018/11/08/182900326/lulusan-smk-penyumbangpenggangguran-tertinggi-ini-kata-menaker-

Sutriyanto, E. (2018). Potensi Industri Kreatif Jakarta Timur Lebih Unggul Dibandingkam Wilayah Lainnya. Diakses pada 23/07/ 2019, dari

http://www.tribunnews.com/metropolitan/2018/05/25/potensi-industri-kreatif-jakartatimur-lebih-unggul-dibandingkam-wilayah-lainnya 